\title{
Expression of NF-kB p65 phosphorylated at serine-536 in rectal cancer with or without preoperative radiotherapy
}

\author{
Andreas Lewander ${ }^{1}$, Jinfang Gao ${ }^{1}$, Gunnar Adell², Hong Zhang ${ }^{3}$, Xiao-Feng Sun ${ }^{1}$ \\ ${ }^{1}$ Department of Oncology, Institute of Clinical and Experimental Medicine, University of Linköping, Linköping, Sweden \\ ${ }^{2}$ Department of Oncology, Karolinska University Hospital, Stockholm, Sweden \\ ${ }^{3}$ Department of Biomedicine, University of Skövde, Sweden
}

Received 16 July 2011

Accepted 8 August 2011

Correspondence to: Prof. Xiao-Feng Sun, M.D., Ph.D., Department of Oncology, Institute of Clinical and Experimental Medicine, University of Linköping, SE-581 85 Linköping, Sweden. Phone: +46-10-10-32066; Fax: +46-10-10-33090; Email: xiao-feng.sun@liu.se

Disclosure: No potential conflicts of interest were disclosed.

\begin{abstract}
Background. In the present study, we investigated NF-kB p65 phosphorylated at Serine-536 (phosphor-Ser536-p65) in rectal cancer and its relationship to preoperative radiotherapy (RT), clinicopathological variables and biological factors.

Patients and methods. Expression of phosphor-Ser536-p65 was examined by using immunohistochemistry in 141 primary rectal cancers, 149 normal mucosa specimens and 48 metastases in the lymph nodes, from rectal cancer patients who participated in a Swedish clinical trial of preoperative RT.

Results. The expression of phosphor-Ser536-p65 in the cytoplasm increased from normal mucosa to primary tumour $(p<0.0001$, for both the group that did and the group that did not received RT). The expression did not further increase from primary tumour to metastasis in either group ( $p>0.05$ ). Expression of phosphor-Ser536-p65 was positively related to, or tended to be related to, the expression of tumour endothelium marker 1 (TEM1, $p=0.02), F X Y D-3$ ( $p=0.001$ ), phosphatase of regenerating liver (PRL, $p=0.02), p 73(p=0.048)$ and meningioma associated protein $(M A C 30, p=0.05)$ in the group that received RT but there were no such relationships in the group that did not received RT $(p>0.05)$. The expression of phosphor-Ser536-p65 was not related to clinicopathological factors including survival ( $p>0.05)$.

Conclusions. The increased expression of phosphor-Ser536-p65 may be involved in rectal cancer development. After RT, phosphor-Ser536-p65 seems to be positively related to the biological factors, which associated with more malignant features of tumours. However, phosphor-Ser536-p65 was not directly related to the response of RT based on recurrence and survival.
\end{abstract}

Key words: NF-KB, serine-536; radiotherapy; rectal cancer; immunohistochemistry; recurrence; prognosis

\section{Introduction}

Nuclear factor-kappaB $(\mathrm{NF}-\kappa \mathrm{B})$ is responsible for expression by regulating many genes for immune response, cell adhesion, differentiation, proliferation, angiogenesis and apoptosis. The function of $N F-\kappa B$ is inhibited by binding to NF- $\kappa$ B inhibitory proteins, and imbalance of NF- $\kappa \mathrm{B}$ and its inhibitors has been associated with development of tumours and other diseases. ${ }^{1-3}$ Five members of the NF- $\kappa B$ family have been found in human cells, RelA (p65), p105/p50, p100/p52, RelB and c-Rel. The most common form in human cells is p65/p50 heterodimer.
The regulation of the NF- $\kappa \mathrm{B}$ protein family is very important. Upon activating signals the inhibitory proteins are degraded and the protein translocates into the nucleus where it exert its effect. The regulation also occurs at the posttranslational level, where protein phosphorylation of the different subunit is one very important mechanism of regulation. Several different phosphorylation sites on the subunits have been discovered. An important site of phosphorylation of p65 subunit is at Serine-536 (phospho-Ser536-p65), and this phosphorylation is involved in regulation of transcriptional activity, nuclear localisation and protein stability..$^{1,2,4,5}$ 
TABLE 1. Characteristics of patients and rectal cancers

\begin{tabular}{|c|c|c|c|c|}
\hline \multirow{2}{*}{ Characteristics } & \multicolumn{2}{|c|}{ Non-Radiotherapy } & \multicolumn{2}{|c|}{ Radiotherapy } \\
\hline & \multicolumn{2}{|c|}{ No. (\%) } & \multicolumn{2}{|c|}{ No. (\%) } \\
\hline $\begin{array}{l}\text { Male } \\
\text { Female }\end{array}$ & $\begin{array}{l}45 \\
34\end{array}$ & $\begin{array}{l}(57) \\
(43)\end{array}$ & $\begin{array}{l}39 \\
23\end{array}$ & $\begin{array}{l}\text { (63) } \\
\text { (37) }\end{array}$ \\
\hline \multicolumn{5}{|l|}{ Age (years) } \\
\hline $\begin{array}{l}\leq 66 \\
>66\end{array}$ & $\begin{array}{l}29 \\
50\end{array}$ & $\begin{array}{l}\text { (37) } \\
\text { (63) }\end{array}$ & $\begin{array}{l}23 \\
39\end{array}$ & $\begin{array}{l}\text { (37) } \\
\text { (63) }\end{array}$ \\
\hline \multicolumn{5}{|l|}{ Stage } \\
\hline $\begin{array}{l}\text { I } \\
\text { IIA } \\
\text { IIIA } \\
\text { IIIB } \\
\text { IIIC } \\
\text { IV }\end{array}$ & $\begin{array}{r}22 \\
18 \\
9 \\
12 \\
14 \\
4\end{array}$ & $\begin{array}{r}(28) \\
(23) \\
(11) \\
(15) \\
(18) \\
(5)\end{array}$ & $\begin{array}{r}16 \\
22 \\
0 \\
16 \\
3 \\
5\end{array}$ & $\begin{array}{r}(25) \\
(36) \\
(25) \\
(5) \\
(8)\end{array}$ \\
\hline \multicolumn{5}{|l|}{ Differentiation } \\
\hline $\begin{array}{l}\text { Well } \\
\text { Moderately } \\
\text { Poorly }\end{array}$ & $\begin{array}{r}5 \\
56 \\
18\end{array}$ & $\begin{array}{l}(6) \\
(71) \\
(23)\end{array}$ & $\begin{array}{r}4 \\
40 \\
18\end{array}$ & $\begin{array}{r}(6) \\
(65) \\
(29)\end{array}$ \\
\hline \multicolumn{5}{|l|}{ Numbers of tumours } \\
\hline $\begin{array}{l}\text { Single } \\
\text { Multiple* } \\
\text { Unknown }\end{array}$ & $\begin{array}{r}68 \\
9 \\
2\end{array}$ & $\begin{array}{r}(86) \\
(11) \\
(3)\end{array}$ & $\begin{array}{r}51 \\
11 \\
0\end{array}$ & $\begin{array}{l}(82) \\
(18)\end{array}$ \\
\hline \multicolumn{5}{|l|}{ Surgical type } \\
\hline $\begin{array}{l}\text { Rectal amputation } \\
\text { Anterior resection }\end{array}$ & $\begin{array}{l}42 \\
37\end{array}$ & $\begin{array}{l}(53) \\
(47)\end{array}$ & $\begin{array}{l}22 \\
40\end{array}$ & $\begin{array}{l}(35) \\
(65)\end{array}$ \\
\hline \multicolumn{5}{|l|}{ Resection margin } \\
\hline $\begin{array}{l}\text { Tumour free } \\
\text { Tumour involved margin }\end{array}$ & $\begin{array}{r}75 \\
4\end{array}$ & $\begin{array}{r}(95) \\
(5)\end{array}$ & $\begin{array}{r}59 \\
3\end{array}$ & $\begin{array}{r}(95) \\
(5)\end{array}$ \\
\hline \multicolumn{5}{|l|}{ Distance to anal verge $(\mathrm{cm})$} \\
\hline Mean & 7.3 & & 8.8 & \\
\hline
\end{tabular}

*Other colorectal cancer or other type of tumour besides the present rectal cancer.

It has also been shown that in some tumours NF- $\kappa B$ activation can enhance radiosensitivity. ${ }^{6,7}$ Preoperative radiotherapy (RT) is today a standard treatment for rectal cancer patients in Sweden and other countries. ${ }^{8}$ It has been shown to increase survival of the patients. ${ }^{9,10}$ In the present study, we investigated whether the phospho-Ser536-p65 was related to response of RT in rectal cancer patients who received or did not receive RT, and whether there were any relationships of the phosphoSer536-p65 with clinicopathological variables and biological factors.

\section{Patients and methods}

\section{Patients}

This study included the patients with rectal adenocarcinoma from the Southeast Swedish Health Care region that participated in a Swedish clinical trial of preoperative RT between 1987 and $1990 .{ }^{9}$ Surgical specimens were obtained by either rectal amputation or anterior resection from 141 patients.
The mean age at diagnosis was 66 years (range 36-85). The mean follow-up time was 83 months (range 0-193). Seventy-nine patients had surgery alone. Sixty-two patients were randomised to preoperative radiotherapy, receiving 25 Gy in 5 fractions over a median of 6 days (range 5-12). Surgery was performed after a median of 3 days (range 1-13) after radiotherapy. The characteristics of the patients and tumours are given in Table 1.

The data regarding expression of tumour endothelium marker 1 (TEM1, unpublished data), FXYD-3 (also known as MAT-8), phosphatase of regenerating liver (PRL, also known as PTP4A3, protein-tyrosine phosphatase), p73 and meningioma associated protein (MAC30) on the same material used as in the present study, determined by immunohistochemistry, were taken from previous studies performed at our laboratory. ${ }^{11-14}$ The number of the patients listed in Table 2 was less than the number of the patients mentioned in the materials of the present study due to available numbers of the previous cases ${ }^{11-14}$, which matched, with the present study. The immunohistochemical staining 
TABLE 2. Expression of NF-KB phosphorylated at Serine-536 in relation to biological factors expressed in rectal cancer

\begin{tabular}{|c|c|c|c|c|c|c|c|c|c|c|}
\hline \multirow{3}{*}{$\begin{array}{l} \\
\text { TEM1 }\end{array}$} & \multicolumn{4}{|c|}{ Non-radiotherapy } & \multirow{2}{*}{$p$-value } & \multicolumn{4}{|c|}{ Radiotherapy } & \multirow{2}{*}{$p$-value } \\
\hline & \multicolumn{2}{|c|}{ Weak (\%) } & \multicolumn{2}{|c|}{ Strong (\%) } & & \multicolumn{2}{|c|}{ Weak (\%) } & \multicolumn{2}{|c|}{ Strong (\%) } & \\
\hline & & & & & & & & & & \\
\hline $\begin{array}{r}\text { Weak } \\
\text { Strong }\end{array}$ & $\begin{array}{r}9 \\
13\end{array}$ & $\begin{array}{l}\text { (39) } \\
(30)\end{array}$ & $\begin{array}{l}14 \\
31\end{array}$ & $\begin{array}{l}\text { (61) } \\
(70)\end{array}$ & 0.43 & $\begin{array}{r}10 \\
8\end{array}$ & $\begin{array}{l}\text { (59) } \\
\text { (25) }\end{array}$ & $\begin{array}{r}7 \\
24\end{array}$ & $\begin{array}{l}(41) \\
(75)\end{array}$ & 0.02 \\
\hline \multicolumn{11}{|l|}{ FXYD3 } \\
\hline $\begin{array}{r}\text { Weak } \\
\text { Strong }\end{array}$ & $\begin{array}{l}13 \\
10\end{array}$ & $\begin{array}{l}(45) \\
(25)\end{array}$ & $\begin{array}{l}16 \\
30\end{array}$ & $\begin{array}{l}(55) \\
(75)\end{array}$ & 0.08 & $\begin{array}{r}13 \\
7\end{array}$ & $\begin{array}{l}\text { (68) } \\
(21)\end{array}$ & $\begin{array}{r}6 \\
27\end{array}$ & $\begin{array}{l}\text { (32) } \\
(79)\end{array}$ & 0.001 \\
\hline \multicolumn{11}{|l|}{ PRL } \\
\hline $\begin{array}{r}\text { Weak } \\
\text { Strong }\end{array}$ & $\begin{array}{r}12 \\
9\end{array}$ & $\begin{array}{l}\text { (34) } \\
\text { (33) }\end{array}$ & $\begin{array}{l}23 \\
18\end{array}$ & $\begin{array}{l}(66) \\
(67)\end{array}$ & 1.00 & $\begin{array}{r}11 \\
5\end{array}$ & $\begin{array}{l}(50) \\
\text { (19) }\end{array}$ & $\begin{array}{l}11 \\
21\end{array}$ & $\begin{array}{l}(50) \\
(81)\end{array}$ & 0.024 \\
\hline \multicolumn{11}{|l|}{ p73 } \\
\hline $\begin{array}{r}\text { Weak } \\
\text { Strong }\end{array}$ & $\begin{array}{r}7 \\
16\end{array}$ & $\begin{array}{l}(29) \\
(36)\end{array}$ & $\begin{array}{l}17 \\
28\end{array}$ & $\begin{array}{l}(71) \\
(64)\end{array}$ & 0.55 & $\begin{array}{l}9 \\
8\end{array}$ & $\begin{array}{l}\text { (56) } \\
(27)\end{array}$ & $\begin{array}{r}7 \\
22\end{array}$ & $\begin{array}{l}(44) \\
(73)\end{array}$ & 0.048 \\
\hline \multicolumn{11}{|l|}{ MAC30 } \\
\hline $\begin{array}{r}\text { Weak } \\
\text { Strong }\end{array}$ & $\begin{array}{r}9 \\
13\end{array}$ & $\begin{array}{l}\text { (31) } \\
\text { (35) }\end{array}$ & $\begin{array}{l}20 \\
24\end{array}$ & $\begin{array}{l}(69) \\
(65)\end{array}$ & 0.73 & $\begin{array}{l}9 \\
8\end{array}$ & $\begin{array}{l}\text { (53) } \\
\text { (25) }\end{array}$ & $\begin{array}{r}8 \\
24\end{array}$ & $\begin{array}{l}(47) \\
(75)\end{array}$ & 0.05 \\
\hline
\end{tabular}

for those factors was performed on the normal mucosa, primary tumour and metastasis in the lymph nodes from both the non-RT and RT groups.

\section{Immunohistochemistry}

Five-micrometer sections were deparaffinised in xylene and rehydrated in graded ethanol. As the method for antigen retrieval we used was highpressure cooking in $0.01 \mathrm{M}$ Tris-EDTA buffer $(\mathrm{pH}$ 9.0). The sections were heated to $125^{\circ} \mathrm{C}$ for $30 \mathrm{sec}$ and then cooled to $90^{\circ} \mathrm{C}$ for $10 \mathrm{sec}$, the sections were then kept in the buffer till room temperature. The sections were incubated with $3 \% \mathrm{H}_{2} \mathrm{O}_{2}$-methanol for $20 \mathrm{~min}$ and washed with phosphate-buffered saline (PBS, pH 7.4). After that the sections were incubated with rabbit anti-phospho-Ser536-p65 antibody (phospho S536, ab28856, Abcam, Cambridge, $\mathrm{MA}$ ) at $20 \mathrm{mg} / \mathrm{ml}$ in antibody diluent (Dako, Carpinteria, CA) overnight, followed by rinsing with PBS. The antibody binds specifically to the Ser536-phosphorylated form of p65 and does not cross-react with non-phosphorylated p65 or any other members of the NF- $\kappa$ B family. Subsequently, the sections were incubated with a goat anti-rabbit/ mouse, coupled with peroxidase provided by the Dako ChemMate EnVision Detection Kit (Dako) for $25 \mathrm{~min}$, and washed with PBS. The peroxidase reaction, using 3,3'-diaminobenzidine tetrahydrochloride, was performed (Dako) for $8 \mathrm{~min}$. Sections known to stain positively were included as positive controls. The negative controls used PBS instead of the primary antibody. In all staining procedures, the positive controls showed clear staining, and there was no staining in the negative controls.
The sections were microscopically examined and scored independently by Lewander A and Gao J without any information on the clinicopathological data. The slides were initially classified as weak including negative ( $<5 \%$ of positive cells) and strong staining in the cytoplasm of normal epithelial cells, and tumour cells and metastasis irrespectively of the percentage of positive cells. To avoid artificial effects, cells in areas with necrosis, with poor morphology, or in the margins of sections were excluded from the analysis.

\section{Statistical analysis}

The significance of the difference in phosphoSer536-p65 expression between normal mucosa, primary tumour and metastasis was tested by Chisquare and McNemar methods. The relationships between phospho-Ser536-p65 expression and clinicopathological/biological variables were examined by Chi-square method, and the relationships to survival were tested by using Cox's proportional hazard model. Survival curves were calculated by using the Kaplan-Meier method. Two-sided p values of $<0.05$ were considered statistically significant.

\section{Results}

Phospho-Ser536-p65 expression in the cytoplasm of normal mucosa, primary tumour and metastasis in the lymph node

When we compared staining intensity of phosphoSer536-p65 expression in the cytoplasm of normal 


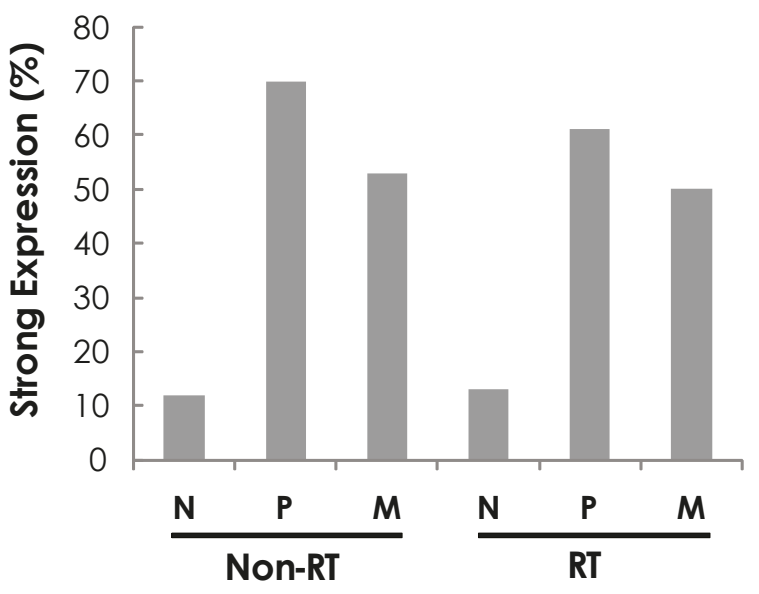

FIGURE 1. Frequency of strong phospho-Ser536-p65 expression in normal mucosa $(N)$, primary tumour $(P)$ and metastasis in the lymph nodes (M) in non-radiotherapy (non-RT) and radiotherapy (RT).

mucosa, primary tumour and metastasis in the lymph node we found significantly more samples with the strong staining of phospho-Ser536-p65 expression in primary tumour than in normal mucosa in the both non-RT and RT groups $(\mathrm{p}<0.0001$ for both Chi-square and McNemar tests for both nonRT and RT groups, Figure 1). There was no significant difference between primary tumour and metastases in either non-RT or RT groups ( $p>0.05$, Figure 1).

We compared phospho-Ser536-p65 expression before and after RT and found there were no differences in normal mucosa $(p=0.06)$, primary tumour $(p=0.30)$ as well as metastases $(p=0.81)$ with chi-square test.

Figure 2 shows phospho-Ser536-p65 expression in normal mucosa, primary tumour and surgical specimens) and metastases in the lymph node. There was weak phospho-Ser536-p65 expression in normal mucosa, while strong expression in the cytoplasm of primary surgical and metastatic tumours.

\section{Phospho-Ser536-p65expression in the cytoplasm in relation to clinicopathological and biological factors}

We compared the expression of phospho-Ser536p65 expression with the expression of TEM1, FXYD3, PRL, p73 and MAC30 (Table 2). PhosphoSer536-p65 expression was positively related to or tended to be positively related to TEM1 $(p=0.02)$, FXYD-3 $(p=0.001)$, PRL $(p=0.02)$ and p73 $(p=0.048)$ and MAC30 $(p=0.05)$ in the RT group. However in the non-RT group, there were no such relationships ( $p>0.05$, Table 2$)$.

We analysed the relationship of phosphoSer536-p65 expression in the cytoplasm of primary tumour with clinicopathological variables and did not find any statistically significant relationship of phospho-Ser536-p65 expression with gender, age, differentiation, stage, local/distant recurrence and survival in the two sub-groups of non-RT and RT, or in the whole group of the patients $(p>0.05$, data not shown).

\section{Discussion}

In this study we examined materials from rectal cancer patients included in the Swedish rectal cancer trial of preoperative $\mathrm{RT}^{9}$, i.e., the patients divided into two groups, one that received and one that did not received preoperative RT.

When we compared staining intensity of phospho-Ser536-p65 expression in the cytoplasm of normal mucosa, primary tumour and metastasis in the lymph node we found significantly more samples with strong staining in primary tumour than in normal mucosa in either the non-RT or RT group. There was no significant difference between primary tumour and metastases in either the non-RT or RT group. Others have found similar results, that NF$\kappa \mathrm{B}$ is upregulated in tumour cells compared with the corresponding normal cells in previous studies. Lind et al. used electrophoretic mobility shift assay (EMSA) technique and demonstrated that NF- $\kappa \mathrm{B}$ in primary tumour was greatly increased compared with adjacent normal tissue from the same patients. ${ }^{15}$ Yu et al. examined the expression of NF- $\kappa B$ p65 by using a monoclonal antibody against NF- $\kappa B$ p65 in normal colorectal mucosa, colorectal adenomas and colorectal adenocarcinomas, and showed that NF- $\kappa \mathrm{B}$ p65 expression was significantly increased from normal mucosa to adenoma and to adenocarcinoma, furthermore the expression was increased with the transition from low to moderate and to high dysplasia of adenoma. ${ }^{16}$ Our previous study in colorectal cancer by immunohistochemistry using the same antibody, showed primary tumour had stronger phospho-Ser536-p65 expression than normal mucosa but had no difference between primary tumours and metastases in the lymph node (unpublished data). Taken together, these results indicate that the NF- $\kappa$ B p65 may play a role in earlier development of colorectal cancer.

In the same materials used here we have previously studied expression of TEM1 (unpublished 


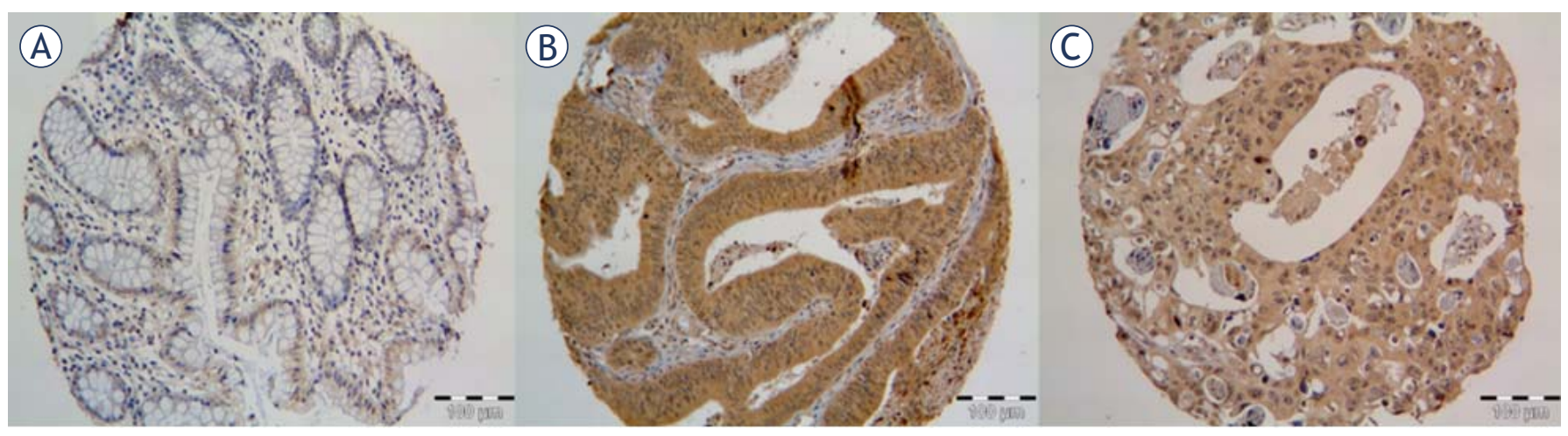

FIGURE 2. The expression of phospho-Ser536-p65 was weak in normal mucosa (A) and strong expression in primary tumour (B) and metastases in the lymph node (C).

data), FXYD3 (9), PRL (11), p73 (10) and MAC30 (12). We found that phospho-Ser536-p65 expression was positively related to TEM1, FXYD-3, PRL, p73 and MAC 30 in tumours that received RT, however there were no such relationships in the nonRT group. TEM1 was expressed on periendothelial mural cells (i.e., pericytes) and activated tumour fibroblasts, probably played a role in the tumour vasculature. ${ }^{17-19}$ In our previous study we found TEM1 expression in the stroma increased from normal mucosa to primary tumour both in the non-RT and RT group. In the RT group, TEM1 expression in the stroma significantly increased from Dukes' A to B-D. FXYD-3 is an 8-kDa trans-membrane protein and acts as a chloride channel or chloride channel regulator. ${ }^{20}$ FXYD-3 is overexpressed in several types of cancers including colorectal cancer. ${ }^{11,20,21} \mathrm{In}$ our previous study, we found that FXYD-3 expression in the primary tumours was, or tended to be increased compared with normal mucosa regardless of RT. Furthermore in the RT group, strong FXYD-3 expression alone or combined with PRL was related to an unfavourable prognosis independent of both, the TNM stage and tumour differentiation, which are important prognostic factors. ${ }^{22}$ In tumours with strong FXYD-3 expression, there were less tumour necrosis and a trend of increased incidence of distant metastasis after RT. None of these effects was seen in the non-RT group..$^{11}$ PRL was identified as an important protein in the metastatic process of colorectal cancer. The PRL family consists of three members, PRL-1, -2 , and -3 . PRL-3, as a tyrosine phosphatase, may play critical roles in the regulation of cellular growth and cell cycle.23,24 We earlier found that PRL expression was increased from normal mucosa to primary tumour. In the RT group, strong PRL expression was related to distant recurrence and poor survival, independent of both stage and differentiation, but not in the non-RT group. Overexpression of $\mathrm{p} 73$ protein has also been correlated with a poor prognosis in colorectal, hepatocellular and breast cancers. ${ }^{25,26}$ In the same material, we earlier found that p73 was overexpressed in rectal cancer compared with normal mucosa. The patients with p73-overexpressing tumours tended to have a higher local recurrence after RT compared to non-RT cases. ${ }^{12}$ MAC30 mRNA is expressed in the foetal liver, but not in the adult liver, suggesting a possible role in growth and differentiation of liver. ${ }^{27,28}$ The expression of MAC30 is stronger in breast, stomach and colorectal cancers than the corresponding normal tissues ${ }^{14,29,30}$, indicating that MAC30 may act as an oncogene in the cancers and might play a role in tumour development and aggressiveness. Why the relationship of phospho-Ser536-p65 expression with TEM1, FXYD-3, PRL, p73 and MAC30 in the RT cases but not in the non-RT cases in this study? One possible speculation is due to the effect of RT, namely, RT resulted in these proteins being more active, temporarily or permanently, and the cells tried to survive. The results may raise a notion that one should consider the targets of RT and the checkpoints controlling the pathways which those factors were involved in. The impact of RT on phospho-Ser536-p65 protein needs to be further investigated in a larger number of patients.

In conclusion, the positive expression of phospho-Ser536-p65 may be involved in rectal cancer development. After RT, the expression of phosphoSer536-p65 was positively related to the biological factors which associated with more malignant features of tumours. However, we did not find that the NF- $\kappa B$ protein was directly related to the response of RT based on local/distant recurrence and survival. 


\section{Acknowledgement}

The study was supported by grants from the Swedish Cancer Foundation, Swedish Research Council and the Health Research Council in the South-East of Sweden. The authors thank Helen Richard, Cecilia Bergenwald, Gertrud Stridh, Gunnel Lindell and Kerstin Ingels, Department of Pathology, Linköping Hospital, Sweden, for kindly preparing tissue sections. We are grateful for the linguist revision by Dr. David Hinselwood.

\section{References}

1. Hanahan D, Weinberg RA. The hallmarks of cancer. Cell 2000; 100: 57-70.

2. Moynagh PN. The NF-kappaB pathway. J Cell Sci 2005; 118: 4589-92.

3. Sun XF, Zhang H. NFKB and NFKBI polymorphisms in relation to susceptibility of tumour and other diseases. Histol Histopathol 2007; 22: 1387-98.

4. Sakurai $H$, Chiba H, Miyoshi $H$, Sugita T, Toriumi W. IkappaB kinases phosphorylate NF-kappaB p65 subunit on serine 536 in the transactivation domain. J Biol Chem 1999; 274: 30353-6.

5. Viatour P, Merville MP, Bours V, Chariot Al. Phosphorylation of NF-kappaB and IkappaB proteins: implications in cancer and inflammation. Trends Biochem Sci 2005; 30: 43-52.

6. Miyakoshi J, Yagi K, Inhibition of IKB- $\alpha$ phosphorylation at serine and tyrosine acts independently on sensitization to DNA damaging agents in human glioma cells. Br J Cancer 2000; 82: 28-33.

7. Yamagashi N, Miyakoshi J, Takebe H. Enhanced radiosensitivity by inhibition of nuclear factor kappa B activation in human malignant glioma cells. Int $J$ Radiat Biol 1997; 72: 157-62.

8. Velenik V, Oblak I; Anderluh F. Quality of life in patients after combined modality treatment of rectal cancer: Report of a prospective phase II study. Radiol Oncol 2008; 42: 207-14

9. Improved survival with preoperative radiotherapy in resectable rectal cancer. Swedish Rectal Cancer Trial. New Eng J Med 1997; 336: 980-7.

10. Velenik V. Locally recurrent rectal cancer: treatment options. Radiol Oncol 2009; 43: 144-51.

11. Loftås $P$, Önnesjö $S$, Widegren $E$, Adell G, Kayed H, Kleeff J, et al. Expression of FXYD-3 is an independent prognostic factor in rectal cancer patients with preoperative radiotherapy. Int J Radiat Oncol Biol Phys 2009; 75: 137-42.

12. Pfeifer D, Gao J, Adell G, Sun X-F. Expression of the p73 protein in rectal cancers with or without preoperative radiotherapy. Int J Radiat Oncol Biol Phys 2006; 65: 1143-8.

13. Wallin Å, Svanvik J, Adell G, Sun X-F. Expression of PRL proteins at invasive margin of rectal cancers in relation to preoperative radiotherapy. Int J Radiat Oncol Biol Phys 2006; 65: 452-8.

14. Zhang ZY, Zhao ZR, Adell G, Jarlstelt I, Cul YX, Kayed H, et al. MAC30 in rectal cancers with or without preoperative radiotherapy. Oncology 2006; 71: 259-65.

15. Lind DS, Hochwald SN, Malaty J, Rekkas S, Hebig P, Mishra G, et al. Nuclear factor-KB is upregulated in colorectal cancer. Surgery 2001; 130: 363-9.

16. Yu HG, Yu LL, Yang Y, LuoH-S, Yu J-P, MeierJJ, et al. Increased expression of RelA/nuclear factor-kappa B protein correlates with colorectal tumorigenesis. Oncology 2003; 65: 37-45.

17. Christian S, Winkler R, Helfrich I, Boos AM, Besemfelder E, Schadendorf D, et al. Endosialin (Tem1) is a marker of tumor-associated myofibroblasts and tumor vessel-associated mural cells. Am J Pathol 2008; 172: 486-94.

18. MacFadyen J, Savage K, Wienke D, Isacke CM. Endosialin is expressed on stromal fibroblasts and CNS pericytes in mouse embryos and is downregulated during development. Gene Expr Patterns 2007; 7: 363-69.
19. Tomkowicz B, Rybinski K, Foley B, Ebel W, Kline B, Routhier E, et al. Interaction of endosialin/TEM1 with extracellular matrix proteins mediates cell adhesion and migration. Proc Natl Acad Sci (USA) 2007; 104: 17965-70.

20. Morrison BW, Moorman JR, Kowdley GC, Kobayashi YM, Jones LR, Leder P. Mat-8, a novel phospholemman-like protein expressed in human breast tumors, induces a chloride conductance in Xenopus oocytes. J Biol Chem 1995; 270: 2176-82.

21. Kayed H, Kleeff J, Kolb A, Ketterer K, Keleg S, Felix K, et al. FXYD3 is overexpressed in pancreatic ductal adenocarcinoma and influences pancreatic cancer cell growth. Int J Cancer 2006; 118: 43-54.

22. Ocvirk J. Advances in the treatment of metastatic colorectal carcinoma. Radiol Oncol 2009; 43: 1-8.

23. Bardelli A, Saha S, Sager JA, Romans KE, Xin B, Markowitz SD, et al. PRL-3 expression in metastatic cancers. Clin Cancer Res 2003;15:5607-15.

24. Sager JA, Benvenuti S, Bardelli A: PRL-3: a phosphatase for metastasis? Cancer Biol Ther 2004;3:952-3.

25. Bénard J, Douc-Rasy S, Ahomadegbe JC. TP53 family members and human cancers. Hum Mutat 2003;21:182-91.

26. Sun XF. p73 overexpression is a prognostic factor in patients with colorectal adenocarcinoma. Clin Cancer Res. 2002;8:165-70.

27. Malhotra K, Luehrsen KR, Costello LL, Raich TJ, Sim K, Foltz L, et al. Identification of differentially expressed mRNAs in human fetal liver across gestation. Nucleic Acids Res 1999;27:839-47.

28. Murphy M, Pykett MJ, Harnish P, Zang KD, George DL. Identification and characterization of genes differentially expressed in meningiomas. Cell Growth Differ 1993;4:715-22.

29. Moparthi S, Arbman G, Wallin $\AA$, Kayed H, Kleeff J, Zentgraf $\mathrm{H}$, et al. Expression of MAC30 protein is related to survival and biological variables in primary and metastatic colorectal cancers. Int J Oncol 2007;30:91-5.

30. Kayed H, Kleeff J, Ding J, Hammer J, Giese T, Zentgraf $\mathrm{H}$, et al. Expression analysis of MAC30 in human pancreatic cancer and tumors of the gastrointestinal tract. Histol Histopathol 2004;19:1021-31. 